\title{
TINDAK TUTUR DALAM SURAT PERJANJIAN KERJA DI PERUSAHAAN MINYAK BOJONEGORO SPEECH ACT IN THE CONTRACT OF AGREEMENT OF BOJONEGORO OIL COMPANY
}

\author{
Arif Izzak \\ Balai Bahasa Jawa Timur \\ Jalan Siwalan Panji 2, No. 1, Buduran, Kec. Sidoarjo, Kabupaten Sidoarjo, Jawa Timur \\ arief_izzak@yahoo.com
}

\begin{abstract}
One of the speech events involving speaker/writer and listener/reader is letter of agreement. This contract of agreement is between employer and employee. This speech event in the form of contract of aggreement is a process of communication built between the company and the employee within which any kinds of speech act are involved and applied in order to negotiate messages. Dealing with this speech act, the writer would like to study kinds of speech act in the letter of aggreement. Writer wants to identify and describe the category of the speech act applied in the contract. This is important since the momentum of signing the contract is the crucial moment with which problems usually come up between employer and employee. This pragmatic study makes use of descriptive method with qualitative approach. The method used in the data analysis is distributional accompanied by subdivision base technique and followed by extended technique. The results are that there are four kinds of speech act which are involved in the contract of aggreement namely, representative speech act, (assertif), commissive speech act, directive speech act, and declarative speech act. Besides those four kinds of speech act, there are also found the mix-speech acts namely, assertivecommissive, directive-commissive, assertive-declarative, and commissive-declarative. Kind of speech act which occurs the most frequently in the contract of aggreement is directive speech act.
\end{abstract}

Keywords: speech act, type and function, contract of working aggreement

\begin{abstract}
Abstrak
Salah satu peristiwa tuturan (speech event) yang melibatkan penutur (speaker/writer) dan petutur (listener) reader), yaitu kontrak perjanjian (contract of agreement). Dalam kaitannya dengan tindak tutur, peneliti mengkaji jenis-jenis dan fungsi tindak tutur menurut teori siapa yang terdapat di dalam surat perjanjian. Metode yang digunakan dalam penelitian ini adalah deskriptif dengan pendekatan kualitatif. Peneliti mengkaji dan menganalisis surat perjanjian menggunakan teori siapa? metode distribusional dengan teknik dasar bagi langsung dan dilanjutkan dengan teknik lanjutan. Hasilnya, terdapat empat jenis tindak tutur di dalam kontrak perjanjian kerja, yaitu tindak tutur representatif (asertif), tindak tutur komisif, tindak tutur direktif, dan tindak tutur deklaratif. Selain keempat jenis tindak tutur tersebut, ditemukan juga jenis tindak tutur campuran, seperti tindak tutur asertif-komisif, tindak tutur direktifkomisif, tindak tutur asertif-deklaratif, dan tindak tutur komisif-deklaratif. Jenis tindak tutur yang paling banyak terdapat dalam kontrak perjanjian kerja adalah tindak tutur direktif.
\end{abstract}

Kata kunci: tindak tutur, jenis dan fungsi, surat perjanjian kerja

\section{Pendahuluan}

Surat perjanjian adalah surat yang dibuat oleh dua pihak yang telah sepakat untuk suatu urusan. Surat perjanjian dibuat sebagai bukti otentik adanya ikatan kedua belah pihak dan untuk menghindari persengketaan di kemudian hari (Wijayanti, 2009).

Selain sebagai peristiwa hukum, surat 
perjanjian juga sekaligus sebagai fenomena kebahasaan, yakni sebuah peristiwa komunikasi yang melibatkan tindak tutur (speech act) dan peristiwa tutur (speech event). Tindak tutur adalah gejala individual, sedangkan peristiwa tutur merupakan peristiwa sosial. Chaer dan Leonie (2010:61) menyebutkan tindak tutur dan peristiwa tutur adalah dua gejala yang terjadi dalam suatu proses, yakni proses komunikasi.

Meskipun bahasa yang digunakan adalah ragam bahasa hukum, surat perjanjian yang baik tetap mensyaratkan adanya pemakaian bahasa yang efektif. Hal ini karena proses komunikasi merupakan proses penyampaian pesan, gagasan dari penutur kepada petutur. Agar tujuan penyampaian pesan dan gagasan tersebut tercapai maka diperlukan pemakaian bahasa yang efektif.

Dalam konteks hubungan sebuah perusahaan dengan karyawan, kontrak kerja ini memiliki fungsi yang sangat penting. Selain untuk mengetahui hak dan kewajiban kedua belah pihak, surat perjanjian ini juga sebagai media komunikasi untuk menyampaikan pesan mengenai aturan dan tata tertib perusahaan termasuk hak dan kewajiban perusahaan dan pekerja.

Peneliti meneliti jenis-jenis dan fungsi tindak tutur dalam surat perjanjian kerja yang ada di perusahaan-perusahaan minyak di Bojonegoro untuk mengetahui struktur umum surat perjanjian berdasarkan aspek jenis dan fungsi tindak tutur (speech act).

Sebagai sebuah peristiwa tuturan, surat perjanjian menjadi alat negosiasi antarpihak dalam sebuah konteks sosial peristiwa tutur (speech event). Dalam konteks ini antara pihak perusahaan sebagai penutur dan calon karyawan sebagai petutur. Surat perjanjian kerja dibuat oleh pihak perusahaan yang di dalamnya berisi proposisi (propositional content) dan daya ilokusi (illocutionary force).

Berdasarkan uraian di atas dapat ditarik sebuah inferensi bahwa surat perjanjian merupakan media yang mempertemukan kepentingan para partisipan dalam peristiwa tutur (speech event). Oleh karena itu, peneliti tertarik untuk meneliti struktur tindak tutur (speech act) dalam surat perjanjian (kontrak) kerja. Pada tahun 2015 Mediawati dan Phahlevy telah melakukan penelitian tentang urgensi sebuah kontrak kerja atau perjanjian kerja. Dalam penelitian ini, mereka mengkaji persoalan kontrak kerja dari aspek legal formal-nya. Metode yang digunakan adalah hukum normatif dengan pendekatan perundang-undangan. Hasil penelitian ini menunjukkan bahwa kontrak kerja dan penyusunannya memiliki peran yang sangat penting dalam relasi antara karyawan dengan instansi atau perusahaannya.

Perjanjian kerja seharusnya menganut azas kesetaraan antara perusahaan pemberi kerja dan karyawannya. Perjanjian kerja adalah "perjanjian antara pekerja/ burub dengan pengusaba atau pemberi kerja yang memuat syarat-syarat kerja, hak, dan kewajiban parapihak", sedangkan hubungan kerja adalah "bubungan antara pengusaha dengan pekerjal burub berdasarkan perjanjian kerja, yang mempunyai unsur pekerjaan, upah, dan perintab" (Mediawati \& Phahlevy, 2015). Dengan demikian, urgensi kontrak digunakan untuk mengikat para pihak dalam ruang kewajiban dan hak masing-masing sehingga dapat mendorong peningkatan kinerja.

Berdasarkan uraian di atas, rumusan masalah penelitian ini adalah sebagai berikut.

a. Bagaimanakah bentuk-bentuk tindak tutur yang terdapat dalam surat perjanjian? 
b. Bagaimanakah fungsi, tujuan, dan aspek pragmatik tindak tutur yang terdapat dalam surat perjanjian?

Berdasarkan rumusan masalah di atas maka tujuan dari penelitian ini dapat dijabarkan sebagai berikut.

a. Mendeskripsikan bentuk-bentuk tindak tutur dalam surat perjanjian.

b. Mendeskripsikan fungsi, tujuan, dan konteks pragmatik tindak tutur dalam surat perjanjian.

Penelitian ini difokuskan pada dua hal, yaitu kajian tentang bentuk atau jenis-jenis tindak tutur (speech act) dan deskripsi fungsi masing-masing jenis tindak tutur. Peneliti ingin mengetahui dan mengidentifikasi struktur surat perjanjian kerja dari perspektif kajian tindak tutur (speech act).

Terkait dengan penelitian tindak tutur, Utami pernah melakukannya pada tahun 2011, yakni mengenai tingkat tutur (undha-usuk dalam bahasa Jawa) dan tindak tutur pada sebuah film berbahasa Perancis. Hasil penelitiannya menunjukkan adanya fungsi tindak tutur direktif, fungsi tindak tutur ekspresif, dan fungsi tindak tutur komisif. Fungsi tindak tutur direktif meliputi fungsi meminta, bertanya, memerintah, melarang, menyetujui, dan menasihati; sedangkan fungsi tindak tutur ekspresif meliputi fungsi tuturan salam, permintaan maaf, penyesalan, terima kasih, ucapan selamat, dan fungsi bela rasa. Fungsi tindak tutur komisif meliputi fungsi tuturan berjanji dan menawarkan.

Penelitian tindak tutur lainnya yang pernah dilakukan adalah yang dilakukan Botha pada tahun 2007 yang dituangkan dalam tulisan dengan judul, "Speech Act Theory and Biblical Interpretation". Penelitian ini lebih menekankan pada justifikasi dan konfirmasi penggunaan pragmatik tindak tutur untuk menganalisis teks tulis berupa Alkitab. Hasilnya mengkonfirmasi bahwa SAT (Speech Act Theory) dengan penekanan pada aspek tindak tutur performatif dapat digunakan untuk menganalisis 'tuturan' berupa teks bahasa tulis. Dalam ujaran, suatu kalimat merupakan penentu maksud kalimat itu.

Perbedaan fundamental penelitian ini dengan yang dilakukan Utami terletak pada sifat data yang menjadi objek kajian. Data penelitian Utami bersifat natural (interaksi langsung) meskipun rekaan (fictional), yaitu percakapan dalam sebuah film, sedangkan data penelitian ini berupa surat perjanjian. Perbedaan lainnya adalah Utami meneliti tindak tutur lisan, sedangkan penelitian ini mengkaji tindak tutur pada naskah tulis.

\section{Pragmatik}

Pragmatik adalah ilmu bahasa yang mengkaji bahasa dan maksud penggunanya berdasarkan konteks yang ada. Dalam penelitian ini bahasa yang dikaji adalah bahasa dalam surat perjanjian kerja yang ada di perusahaan minyak. Hanya dengan ilmu pragmatik kalimat-kalimat di dalam surat perjanjian kerja dapat dianalisis seberapa jauh kalimat-kalimat tersebut memiliki efek bagi pihak-pihak yang terlibat dalam perjanjian.

Definisi pragmatik menurut Strazny (Ed. 2005) dalam Encyclopedia of Linguistics Vol. 1 adalah the study of language use, 'studi tentang pemakaian bahasa'. Jika dalam kajian tata bahasa (grammar and structure) fokus kajiannya berada pada sistem bahasanya, pragmatik mengkaji bagian di luar sistem bahasanya, yaitu pilihan-pilihan linguistik penggunanya di dalam sistuasi sosial tertentu. Sejalan dengan Strazny, Leech dalam bukunya Principle of Pragmatics mengemukakan bahwa pragmatik adalah studi mengenai makna ujaran di dalam situasi-situasi 
tertentu (Rustono,1999:2).

Definisilain diberikan olehBlack(terjemahan, Davies dan Mitchell:Ed.). Menurut Black, pragmatik adalah kajian terhadap bahasa dalam penggunaannya dengan memperhitungkan unsur-unsur yang tidak dicakup oleh tata bahasa dan semantik (2011:2). Dari kedua definisi di atas dapat disimpulkan bahwa pragmatik tidak mengkaji sistem bahasanya, tetapi pemakaiannya oleh pengguna bahasa tersebut dalam konteks dan situasi sosial tertentu. Selanjutnya, Verhaar (2008:14) mengatakan bahwa pragmatik merupakan cabang ilmu linguistik yang membahas apa yang termasuk struktur bahasa sebagai alat komunikasi antara penutur dan pendengar, dan sebagai pengacuan tanda-tanda bahasa pada hal-hal 'ekstralingual' yang dibicarakan.

\section{Teori Tindak Tutur (Speech Act Theory)}

Konsep mengenai tindak ujaran (Speech Acts) dikemukakan pertama oleh John L. Austin dengan bukunya How to Do Things with Words (1962). Austin menyebutkan bahwa konsep dasar teori tindak tuturnya adalah tindakan yang dilakukan melalui tuturan. Bahwa pada dasarnya, melakukan tindak ujaran adalah melakukan sebuah tindakan.

Istilah tindak tutur (speech act) umumnya disandingkan dengan peristiwa tutur (speech event) dan situasi tutur (speech situation) karena tindak tutur umumnya terjadi pada suatu peristiwa dan situasi tutur tertentu. Tindak tutur menurut Yule (1996:47) didefinisikan dengan, actions performed via utterances, 'tindakan yang dilakukan melalui ujaran'.

Pernyataan adalah hal dasar dalam teori tindak tutur Austin yang menurut istilahnya disebut dengan 'konstatif'. Dalamkonteksinipernyataan konstatif dikontraskan dengan 'performatif'. Makna konstatif adalah pernyataan yang dapat diberikan label 'benar-salah', sedangkan performatif tidak dapat diberikan label 'benarsalah' karena ujaran performatif ini digunakan untuk melaksanakan tindakan sehingga tidak relevan untuk mempertanyakan kondisi kebenarannya. Misalnya, dalam hal seseorang mengucapkan janji untuk melakukan tindakan di masa yang akan datang. Dalam konteks ini tidak bisa kita merespons janji tersebut dengan mengatakan, "Itu tidak benar". Perbedaan dasar antara pernyataan konstatif dengan performatif, yaitu konstatif merupakan pernyataan deskripsi yang dapat diketahui kondisi kebenarannya, sementara performatif adalah untuk melakukan tindakan sehingga tidak dapat dinilai kondisi kebenarannya.

a. Saya berjanji akan membayar utang saya besok lusa.

b. Saya nyatakan bahwa saya tidak bersalah.

Kalimat(a)adalah contohkalimatperformatif dengan verba performatif 'berjanji'. Kalimat (a) ini tidak logis jika direspons dengan kalimat, 'itu tidak benar' karena verba 'berjanji' diujarkan untuk melakukan tindakan berikutnya, yaitu membayar utang.

Demikian pula dengan contoh kalimat (b). Kalimat ini juga menunjukkan verba 'nyatakan' adalah verba performatif karena untuk melakukan tindakan membuat pernyataan bahwa saya tidak bersalah. Kalimat ini tidak dapat direspons dengan menyatakan bahwa kalimat ini benar atau salah. Kalimat tersebut tidak dapat diuji kebenarannya.

Secara pragmatis ada tiga jenis tindakan yang diwujudkan oleh seorang penutur, yakni tindak lokusi (locutionary act), tindak ilokusi (illocutionary 
act), dan tindak perlokusi (perlocutionary act) (Austin dalam Searle, 1974:23-24; Mey 1993:236).

Tindak lokusi adalah tindak tutur yang menyatakan sesuatu (the act of saying something). Konsep ini berkaitan dengan proposisi kalimat, yaitu di dalamnya terdapat subjek/topik dan predikat (Wijana, 1996: 17). Dalam hal ini tindak lokusi merupakan tuturan sebuah kalimat yang memiliki maksud dan referen yang sudah jelas.

Tindak ilokusi merupakan tuturan selain berfungsi untuk mengatakan sesuatu atau menginformasikan sesuatu, dapat juga dipergunakan untuk melakukan sesuatu (the act of doing something). Untuk menafsirkan tindak ilokusi ini diperlukan pemahaman terhadap situasi tutur karena pemaknaan tindak tutur ini dipengaruhi oleh aspek situasi tutur.

Tindak perlokusi (perlocution act) adalah tindak tutur yang mengharapkan respons dari mitra tutur terhadap tuturan yang dituturkan oleh penutur, baik berupa tindakan maupun jawaban (the act of affecting someone).

Yule (1996:53) memberikan lima jenis klasifikasi fungsi tindak tutur, yaitu: deklarasi (declaration), representasi (representatives), ekspresif (expressives), direktif (directives), dan komisif (commissives). Klasifikasi yang diberikan oleh Yule senada dengan apa yang disebutkan oleh Rustono (1999:39) yang membagi fungsi performatif tindak tutur menjadi lima kategori.

Yang ditekankan di atas fungsi tindak tutur yang sama dengan rumusan masalah ke-2.

\section{Metode Penelitian}

Penelitian ini didasarkan pada dua aspek dasar, yaitu penelitian yang bersifat naturalistik dan tujuannya adalah untuk memahami sebuah fenomena kebahasaan tertentu dan dalam konteks tertentu (Moleong, 2006:5-6).
Penelitian ini dilaksanakan dalam tiga tahap, yaitu pengumpulan data, analisis data, dan tahap penyajian hasil analisis data. Metode yang digunakan dalam tahap pengumpulan data adalah metode simak dengan teknik dasar sadap. Mahsun (2007:92) berkata bahwa pada dasarnya metode simak dalam sebuah penelitian adalah melakukan penyadapan terhadap penggunaan bahasa oleh informan. Meskipun korpus data tidak langsung berasal dari informan, pada prinsipnya peneliti melakukan tindakan menyimak dan mencatat setiap satuan lingual analisis berupa kalimat-kalimat yang mengandung verba di dalam klausul-klausul surat perjanjian kerja di perusahaan minyak Bojonegoro.

Pada tahapanalisisdata, penelitimenggunakan metode padan ekstralingual dengan teknik hubung banding. Peneliti menentukan satuan bahasa yang dianalisis, yaitu kalimat-kalimat yang terdapat di dalam surat perjanjian kerja dan menghubungbandingkannya dengan aspekaspek di luar bahasa, misalnya dengan konteks tuturan, koteks, atau partisipan tuturan (Mahsun, 2007:120). Setelah dipilah, kalimat dibagi ke dalam unsur-unsurnya dengan teknik bagi unsur langsung dan menganalisnya berdasarkan kategorisasi verba. Data dianalisis secara deskriptif sebagai konsekuensi dari metode penelitian kualitatif, yakni penelitian dengan data-data yang berupa kata-kata, gambar, dan bukan angka-angka.

Sumber data diperoleh dari dokumen surat perjanjian kerja tahun 2012, sementara satuan lingual verba tindak tutur yang terdapat di dalam teks dokumen merupakan satuan lingual yang dianalisis.

Sumber data primer berupa dokumen surat perjanjian kerja tahun 2012 dari perusahaan 
minyak Tri Patra, di Bojonegoro. Peneliti bertindak sebagai instrumen pengumpul data. Sugiyono (2009:305) menyatakan bahwa dalam penelitian kualitatif, yang menjadi instrumen atau alat penelitian adalah peneliti itu sendiri.

Teknik penyediaan data dalam penelitian ini dengan menggunakan teknik purposive sampling. Maksud dari penggunaan teknik sampling bertujuan ini adalah untuk menjaring sebanyak mungkin informasi dari berbagai macam sumber data dan bangunannya (construction) (Moleong, 2006:224).

MenurutSapsford \& Jupp (2006) keuntungan menggunakan sumber data dari dokumen tertulis adalah dokumen ini tersedia banyak sekali di instansi-instansi atau kepemilikan pribadi.

Analisis data dilakukan berdasarkan pada kumpulan data yang sudah didapat untuk selanjutnya dilakukan pemilahan, pengkategorisasian, kemudian analisis, dan interpretasi data. Analisis data tujuannya untuk mengetahui bagaimana bentuk-bentuk tindak tutur yang ada dalam dokumen surat perjanjian kerja dan fungsi, tujuan, dan konteks pragmatik dari peristiwa tutur dalam dokumen surat perjanjian kerja.

Kajian tindak tutur ini tidak hanya berkaitan dengan tuturan langsung dari pembicara atau penutur kepada petutur atau pendengar yang mengisyaratkan adanya komunikasi lisan, tetapi juga melibatkan tuturan dalam ranah tulis. "Pragmatics is concerned with the study of meaning as communicated by a speaker (or writer) and interpreted by listener (or reader) (Ibid:3). Proses berbahasa dalam praktik komunikasi untuk menyampaikan pesan dari penutur (speaker) kepada petutur (listener) tidak hanya bersifat langsung dalam bentuk lisan, tetapi bisa juga dalam bentuk tulis, yaitu proses komunikasi antara penulis (writer) dan pembaca (reader).

\section{Hasil dan Pembahasan}

Peristiwa tutur (speech event) merupakan peristiwa sosial yang mensyaratkan harus hadirnya minimal pembicara/peneliti dan pendengar/pembaca yang berinteraksi dan untuk penyampaian pesan/amanat mengenai topik-topik tertentu dan di tempat-tempat dan waktu tertentu pula.

Menurut Hymes yang disitir Rustono (1999:21) faktor-faktor yang menandai adanya sebuah peristiwa tutur ada delapan: setting atau scene 'tempat peristiwa tuturan berlangsung'; participant'siapa saja yang terlibat dalam peristiwa tutur tersebut, bisa penutur, pendengar, atau pihak ketiga lainnya'; end 'tujuan dari adanya peristiwa tutur'; act 'tindakan yang dilakukan oleh penutur dalam sebuah peristiwa tutur'; key 'nada suara atau ragam bahasa yang digunakan untuk mengekspresikan tuturan yang dimaksud'; instrument 'ekspresi itu bisa lisan bisa juga tulis. Bisa dengan bersemuka atau dengan telpon'; norm 'norma atau aturan yang sudah disepakati bersama, baik oleh penutur maupun oleh pendengar'; genre mengekspresikan jenis atau bentuk kegiatan atau peristiwa tutur, misalnya apakah berupa wawancara, diskusi, kampanye, khotbah, pidato, dan sebagainya.

Dalam sebuah ekspresi, baik lisan maupun tulis mengetahui siapa penuturnya merupakan salah satu cara untuk memudahkan interpretasi maksud atau tujuan dari ekspresi tersebut. Misalnya, dalam kalimat: Pibak pertama mempekerjakan pihak kedua di proyek pibak pertama.

Tanpa mengetahui siapa penuturnya (penyusun surat perjanjian) pembaca sulit 
mengetahui maksud dari kalimat di atas. Untuk mengetahui siapa yang menjadi pihak pertama dan siapa yang menjadi pihak kedua harus ada koteks yang mendahului ekspresi kalimat tersebut.

Ekspresi 'jauh' dan 'dekat' tentu juga memiliki tafsiran yang berbeda-beda tergantung siapa yang menuturkan. Dengan mengetahui siapa penuturnya maka akan mempermudah memahami maksud dari sebuah ekspresi. Jika orang yang tinggal di daerah pegunungan mengatakan, "jaraknya dekat dari sini" (konteks: sedang memberikan petunjuk kepada orang asing) akan berbeda jika orang yang tinggal di kota yang mengatakan ekspresi tersebut. Seperti diketahui bahwa kontur, keadaan geografis daerah pegunungan sangat sulit diukur dengan jarak yang pasti. Ini berbeda dengan di daerah perkotaan yang dengan mudah mengukur jarak suatu tempat dengan pasti.

Topik tuturan juga hal yang penting dalam sebuah peristiwa tutur. Saat seseorang ikut terlibat dalam sebuah pembicaraan (peristiwa tutur) apalagi jika dia tidak mengikuti pembicaraan tersebut dari awal tentu akan kesulitan mengikuti dan memahami setiap ekspresi yang keluar dalam peristiwa tutur tersebut. Biasanya, kita akan bertanya langsung kepada peserta tutur lain topik apa yang sedang dibicarakan. Perhatikan kalimat berikut.

\section{Strukturnya sangat bagus.}

Jika kita tidak tahu topik saat ujaran di atas muncul dalam sebuah peristiwa tutur, sulit untuk mengetahui maksud dari eskpresi tersebut. Kita tidak tahu struktur apa yang dimaksud. Bagi penjual hewan ternak untuk kurban, struktur bisa berarti bentuk kaki hewan, tetapi bagi seorang arsitek atau kontraktor struktur bisa berarti bentuk bangunan.
Waktu dan tempat terjadinya tuturan adalah salah satu konteks yang membangun latar sebuah peristiwa tutur. Dengan mengetahui latar terjadinya sebuah peristiwa tutur maka akan semakin mempermudah memahami maksud dari sebuah tuturan atau ekspresi. Latar waktu dan tempat bersama dengan faktor mimik atau bahasa tubuh dapat membantu memahami maksud dari sebuah tuturan.

Tindak tutur berdasarkan pembagian jenisjenis tindak tutur Yule (2006) dideskripsikan dengan menggunakan kata-kata dan tabel untuk lebih memperjelas deskripsi.

PT Tri Patra adalah salah satu subkontraktor dari Exxon Mobil yang memenangkan tender dalam proyek migas Banyu Urip, Bojonegoro. Sebagai subkontraktor yang menangani proyek EPC 1, perusahaan menyerap tenaga kerja lokal dan luar daerah selain dari tenaga kerja asing. Dalam proses perekrutan karyawan, perusahaan menerapkan sistem kontrak kerja dengan membuat surat perjanjian kerja. Setiap calon karyawan yang akan bekerja di perusahaan tersebut harus menandatangani surat perjanjian yang sudah disusun oleh pihak perusahaan.

Kontrak kerja atau perjanjian kerja merupakan dokumen resmi dan bersifat legal formal. Karena sifatnya yang sangat formal akibat adanya tuntutan dari pihak-pihak yang membuat perjanjian, maka bahasa yang digunakan harus bahasa-bahasa yang tegas dan tidak multitafsir. Hal ini dilakukan untuk menjaga kemungkinan-kemungkinan yang tidak diinginkan di kemudian hari selama perjanjian berlangsung antara pihak pertama (perusahaan) dan pihak kedua (pekerja).

Orientasi kalimat dan bahasanya ditujukan kepada semua pihak yang diikat dalam perjanjian tersebut. Dengan demikian, status antara pihak 
pertama dan pihak kedua, meskipun pada kenyataannya berbeda, di dalam perjanjian tersebut sama. Pilihan verba kalimatnya juga tidak mengekspresikan pihak yang satu lebih tinggi posisinya dibanding pihak yang lain. Oleh sebab itu, dalam sebuah perjanjian, referen yang digunakan umumnya adalah orang ketiga untuk menjaga agar isi perjanjian tidak memihak salah satu pihak, baik pihak pertama maupun pihak kedua. Pronomina pelibat dalam sebuah perjanjian kerja menggunakan kata 'pihak' yang mengacu kepada orang ketiga dan lebih bersifat netral.

Dalam dokumen perjanjian kerja ini, pihak pertama mewakili perusahaan merekrut karyawan dan pihak kedua, yaitu karyawan yang akan bekerja untuk pihak pertama. Naskah perjanjian kerja ini disusun oleh pihak perusahaan yang dalam hal ini diwakili oleh manajer proyek. Kontrak kerja pada akhirnya akan ditandatangani oleh kedua belah pihak dan masing-masing pihak merasa tidak dirugikan dengan ditandatanganinya surat perjanjian kerja tersebut. Yang sering menjadi masalah apabila pihak kedua, yaitu yang akan dipekerjakan tidak memahami isi dari perjanjian kerja tersebut.

Berikut ini deskripsi tentang fungsi tindak tutur.

a. Tindak Tutur Deklarasi (declarations)

...declarations are those kinds of speech acts that change the world via utterance. "deklarasi adalah jenisjenis tindak tutur yang mengubah dunia melalui ujaran'. (Yule:1996). Sementara itu, Rustono (1999) menyebutkan bahwa tindak tutur deklarasi adalah tindak tutur yang dimaksudkan oleh penuturnya untuk menciptakan hal (status, keadaan, dsb.) yang baru. Tuturan-tuturan dengan maksud mengesabkan, memutuskan, membatalkan, melarang, mengizinkan, mengabulkan, mengangkat, menggolongkan, mengampuni, dan memaafkan termasuk ke dalam tindak tutur deklarasi (Rustono, 1999:43).

Data penelitian yang termasuk dalam jenis tindak tutur deklarasi ini adalah sebagai berikut.

- Perjanjian ini dibuat dan berlaku terhitung mulai tanggal ... (D.5)

- Pihak Kedua berhak atas cuti selama 12 hari kerja ... (D.19)

- Pihak Pertama dapat memberikan ijin kepada Pihak Kedua ... (D.22)

- Hari dan Jam kerja normal ... akan tunduk pada ketentuan yang berlaku ... (D.25)

- Hari libur di ... adalah Sabtu dan hari libur resmi ... (D.26)

- ... Pihak Kedua dianggap tidak masuk kerja tanpa ijin ... (D.70)

- ... maka pihak kedua dianggap mengundurkan diri.(D.72)

- .... Pihak kedua tidak diperkenankan membuka rahasia perusahaan pihak pertama ... (D.77)

- Pihak pertama tidak terikat pada janji-janji lisan ... (D.79)

- Pihak pertama dan pihak kedua sepakat untuk membuat perjanjian kerja untuk waktu tertentu ... (D.81)

\section{b. Tindak Tutur Representatif (representatives)/Asertif}

Tindak tutur representatif ini dinamakan juga dengan tindak tutur asertif. ... are those kinds of speech acts that state what the speaker believes to be the case or not, 'jenis-jenis tindak tutur yang menyatakan bahwa penutur atau pembicara percaya akan apa yang diutarakannya. Dengan kata lain, tindak tutur yang mengikat penuturnya akan kebenaran atas apa yang telah diujarkan 
(Rustono, 1999:40). Yang termasuk dalam tindak tutur ini adalah tuturan menyatakan, menuntut, mengakui, melaporkan, menunjukkan, menyebutkan, memberikan, kesaksian, dsb. pada tuturan "dia yang mencuri sandal di masjid kemarin", si penutur terikat dengan kebenaran isi tuturan yang dia ujarkan.

Untuk menguji kebenaran tuturan tersebut perlu pengetahuan di lapangan bahwa benarbenar dia yang mencuri sandal di masjid itu. Penutur bertanggung jawab terhadap kebenaran isi tuturan. Penutur juga mempercayai isi tuturan yang dia ujarkan. Tuturan representatif ini juga dinamakan dengan tuturan asertif, yaitu pernyataan yang diyakini kebenarannya oleh si penutur, misalnya pada tuturan, "Jalan itu rusak parah."

Data penelitian yang termasuk jenis tindak tutur ini adalah sebagai berikut.

- Pihak Pertama setuju mempekerjakan Pihak Kedua ... (D.1)

- Pihak Pertama mempekerjakan Pihak Kedua di proyek ... (D.2)

- Tugas pekerjaan yang wajib dikerjakan Pihak Kedua sesuai dengan uraian pekerjaan ... (D.3)

- Jika diperlukan perjanjian ini dapat diperpanjang sesuai dengan ketentuan yang berlaku ... (D.6)

- Pihak kedua selain menerima upah ... berhak atas insentif kehadiran ... (D.8)

- $\quad$ Selain yang disebutkan ... premi asuransi ditanggung oleh Pihak Pertama ... (D.18)

- Kerja lembur ... harus mendapatkan persetujuan pihak pertama ... (D.32)

- Perjanjian kerjawaktu tertentuiniberakhir demi hukum dengan berakhirnya waktu ... (D.74)

\section{c. Tindak Tutur Asertif-Komisif}

Bentuk tindak tutur ini tidak hanya mengikat penuturnya untuk melaksanakan apa yang dituturkannya, tetapi juga dapat diartikan oleh mitra tuturnya (dalam hal ini pihak kedua) sebagai sebuah ancaman. Unsur adanya ancaman ini berdasarkan perspektif dari pihak kedua meskipun tidak dinyatakan secara eksplisit dalam tindak tutur komisif.

Data bentuk tindak tutur asertif-komisif dalam penelitian ini adalah sebagai berikut.

Bila dipandang perlu Pihak Pertama dapat memberikan tugas dan pekerjaan di tempat lain ... (D.4)

- Pembayaran upah ... akan dibayarkan oleh Pihak Pertama kepada Pihak Kedua selambat-lambatnya ... (D.9)

- Pembayaran insentif ... akan dibayarkan oleh Pihak Pertama kepada Pihak Kedua pada ... (D.10)

- Pihak Pertama akan memberikan kepada Pihak Kedua ... (D.17)

- $\quad$ Ijin meninggalkan ... dapat diberikan oleh Pihak Pertama setelah ... (D.24)

- Upah lembur bulan berjalan dibayarkan kepada Pihak Kedua ... (D.31)

Jika Pihak Kedua ... Pihak Pertama berhak memberikan peringatan terakhir ... (D.66)

... Pihak Pertama berhak memutuskan hubungan kerja ... (D.67)

... Pihak Pertama berhak memutuskan hubungan kerja ... tanpa perlu peringatan terlebih dahulu ... (D.68)

...pihak pertama berhak menggunakan segala upaya hukum ... (D.78)

\section{d. Tindak Tutur Direktif (directives)}

Tindak tutur direktif adalah jenis tuturan 
untuk membuatoranglain melakukan seperti apa yang dituturkan. Maksud dari tuturan direktif tidak lain agar orang lain melakukan seperti apa yang dituturkan. Tuturan ini mengungkapkan keinginan dari si penutur melalui tuturannya kepada orang lain. Jenis tuturan ini termasuk perintah, permintaan, saran, pesan, dan sebagainya. Tuturan ini dapat berupa tuturan negatif dapat juga positif. Contoh:

- Jangan injak rumput itu!

- Tolong ambilkan tasku!

- Bolehkah aku pinjam uangmu?

Contoh tindak tutur direktif dalam surat perjanjian kerja

- $\quad$... Pihak Kedua harus memberitahukan rencana perubahan ... (D.12)

- Pihak Kedua harus mengajukan permohonan ... (D.20)

- $\quad$ Ijin meninggalkan ... harus diperoleh terlebih dahulu ... (D.23)

- Pihak Kedua wajib melaksanakan pekerjaan tersebut ... (D.28)

- Pihak Kedua wajib melakukan kerja lembur ... (D.29)

- Pihak Kedua wajib menjaga kesehatan rohani dan jasmani ... (D.33)

- Pihak Kedua wajib berada di tempat tugas masing-masing tepat waktu ... (D.34)

- Pihak Kedua wajib mencatatkan kehadiran ... (D.35)

- Pihak Kedua wajib mengikuti dan mematuhi seluruh petunjuk atau instruksi ... (D.36)

- Pihak Kedua wajib melaksanakan seluruh tugas ... (D.37)

- Pihak Kedua wajib menunjukkan prestasi kerja yang baik ... (D.38)

- Pihak Kedua wajib memelihara dan memegang teguh rahasia perusahaan ... (D.39)

Pihak Kedua wajib melaporkan kepada perusahaan ... (D.40)

Pihak Kedua wajib memeriksa semua alat-alat kerja ... (D.41)

- Pihak Kedua wajib memelihara dan menjaga barang-barang, data, dan informasi milik perusahaan ... (D.42)

- Pihak Kedua wajib menjaga ketertiban, kebersihan, dan keserasian lingkungan kerja ... (D.43)

Pihak Kedua wajib bekerja dengan jujur, tertib, cermat, dan penuh kesadaran ... (D.44)

Pihak Kedua wajib memelihara dan meningkatkan kekompakan ... (D.45)

- $\quad$ Pihak Kedua wajib menciptakan suasana kerja yang baik ... (D.46)

Pihak Kedua wajib memberikan pelayanan dengan sebaik-baiknya ... (D.47)

Pihak Kedua wajib berpakaian rapi dan sopan ... (D.48)

Pihak Kedua wajib bersikap dan bertingkah laku sopan terhadap ... (D.49)

Pihak Kedua wajib menolak setiap pemberian atau janji ... (D.50)

Pihak Kedua wajib menolak atau tidak melakukan pekerjaan di perusahaan yang sama ... (D.51)

Pihak Kedua wajib menjaga, memelihara, dan meningkatkan nama baik Pihak Pertama ... (D.52)

Pihak Kedua wajib menghindari perbuatan yang tercela ... (D.53) ...hal itu harus dibuktikan dengan surat keterangan dokter ... (D.69) 


\section{e. Tindak Tutur Komisif (commissives)}

... are those kinds of speech acts that speakers use to commit themselves to some future action. "jenis-jenis tindak tutur yang mengikat penuturnya untuk melaksanakan apa yang dituturkan', misalnya berjanji, bersumpah, mengancam, menyanggupi, dan sebagainya.

Pada tuturan "saya sanggup mengerjakannya sendiri”, penuturmengikatdiriatauberkomitmen untuk dapat melaksanakan apa yang dituturkan pada masa yang akan datang. Karakteristik tuturan komisif ini adalah tindakan yang belum dilakukan atau akan dilakukan di masa yang akan datang.

Data tindak tutur komisif di dalam surat perjanjian kerja adalah sebagai berikut.

- $\quad$... Pihak Pertama akan membayar upah kepada Pihak Kedua ... (D.7)

- Pihak Pertama akan memberikan Tunjangan Hari Raya ... (D.14)

- Pihak Pertama akan memberikan Tunjangan Hari Raya ... (D.15)

- Perusahaan dapat memberikan sanksi peringatan ... (D.65)

- ... maka pihak yang mengakhiri harus membayar ganti rugi ... (D.76)

\section{f. Tindak Tutur Direktif-Komisif}

Selain bersifat imposisi terhadap pihak kedua, yaitu agar lawan tutur melakukan tindakan yang disebutkan di dalam tuturan, tindak tutur jenis ini juga menyiratkan makna menyatakan kesanggupan bagi pihak pertama.

Data bentuk tindak tutur direktif-komisif dalam penelitian ini adalah sebagai berikut.

- Pembayaran upah dan insentif ... akan dilakukan melalui transfer kepada rekening ... (D.11)

- Perusahaan akan memotong, menyetor, dan melaporkan ... (D.13)

\section{g. Tindak Tutur Asertif-Deklaratif}

Selain mengikat penutur (pihak pertama) akan kebenaran atas apa yang dituturkan (ditulis dalam klausul) tindak tutur ini juga dimaksudkan untuk menciptakan status yang baru terkait dengan perjanjian kerja tersebut.

Data penelitian yang termasuk dalam jenis tindak tutur ini adalah sebagai berikut.

- $\quad$ Pekerja yang masa kerjanya kurang...tidak berhak atas THR ... (D.16)

- Pihak Pertama tidak akan membayar cuti tahunan Pihak Kedua ... (D.21)

Perhitungan upah lembur ... berdasarkan pada peraturan ketenagakerjaan ... (D.30)

Pihak Kedua dilarang menerima imbalan baik langsung maupun tidak langsung ... (D.54)

- Pihak Kedua dilarang membawa/ menggunakan ... (D.55)

Pihak Kedua dilarang menyalahgunakan wewenangnya ... (D.56)

Pihak Kedua dilarang membawa senjata api/tajam ke dalam lingkungan kerja ... (D.57)

- Pihak Kedua dilarang melakukan tindakan-tindakan sabotase...(D.58)

Pihak Kedua dilarang membujuk, menghasut ... agar karyawan tidak masuk kerja ... (D.59)

Pihak Kedua dilarang meninggalkan tempat pekerjaan pada waktu jam kerja ... (D.60)

- Pihak Kedua dilarang menulis/ mencorat-coret di lingkungan perusahaan ... (D.61)

- Pihak Kedua dilarang melakukan pekerjaan yang bukan tugasnya ... (D.62)

- Pihak Kedua dilarang menjual/ 
memperdagangkan barang-barang apapun ... (D.63)

- Pihak Kedua dilarang tidur di tempat kerja ... (D.64)

- Hal-hal yang belum dicantumkan dalam perjanjian ini tunduk pada peraturan ... (D.80)

\section{h. Tindak Tutur Komisif-Deklaratif}

Selain mengikat penuturnya (pihak pertama) untuk melaksanakan apa yang disebutkan di dalam tuturannya, bentuk tindak tutur ini juga dimaksudkan untuk menciptakan hal atau status baru dalam kaitannya dengan perjanjian kerja dengan pihak kedua.

Data penelitian yang termasuk dalam bentuk tindak tutur jenis ini adalah sebagai berikut.

... upah Pihak Kedua dikurangi sebesar ...

- ...maka pihak pertama berhak memutuskan hubungan kerja dengan pihak kedua tanpa ... (D.73)

- Pihak kedua tidak berhak memperoleh uang pesangon ... pada saat perjanjian ini berakhir ... (D.75)

\section{Fungsi Tindak Tutur dalam Surat \\ Perjanjian Kerja}

Berdasarkan hasil analisis data, fungsi tindak tutur yang termasuk dalam kategori direktif paling banyak muncul dalam surat perjanjian kerja (27 kali). Fungsi direktif ini menandakan sistem tuturan yang tidak setara dan sifatnya 'imposisi' atau memaksa. Hal ini menunjukkan bahwa bahasa dalam surat perjanjian kerja bersifat sepihak dan tidak bebas kepentingan.

Dominannya fungsi tindak tutur direktif di dalam surat perjanjian kerja jelas menunjukkan sifat tuturannya banyak yang bersifat imposisi atau 'memaksa' sehingga dalam konteks ini pihak kedua (pekerja) mau tidak mau, suka atau tidak suka harus tunduk pada ketentuan (tuturan) yang ada yang sudah dipersiapkan sebelumnya. Indikator imposisinya bisa dilihat dari pemakaian kata-kata 'wajib' dan 'harus' pada fungsi predikat kalimatnya. Dengan demikian dapat dikategorikan sebagai eksplisit performatif, yaitu jelas disebutkan apa yang harus dilakukan oleh mitra tutur sesuai dengan apa yang dituturkan.

Fungsi tindak tutur ekspresif tidak muncul di dalam surat perjanjian kerja karena bahasa dalam surat formal adalah bahasa yang tegas dan eksplisit. Makna tuturan dalam surat perjanjian tidak melibatkan rasa karena lebih bersifat imposisi, memaksa. Tidak ada pilihan lain bagi pihak kedua selain harus tunduk dan mengikuti aturan (tuturan) yang sudah ada.

Semua jenis tindak tutur, kecuali jenis tindak tutur ekspresif, ditemukan dalam surat perjanjian kerja. Jenis-jenis tindak tutur yang paling banyak ditemukan dalam surat perjanjian kerja ini adalah jenis tindak tutur direktif (27) kemudian diikuti oleh asertif-deklaratif (15), deklaratif (10), asertif-komisif (10), asertif (8), komisif (6), komisif-deklaratif (3), dan direktifkomisif (2).

Terkait dengan larangan yang harus dipatuhi oleh pihak kedua, maka fungsi tindak tutur deklaratif juga banyak muncul dalam bahasa di surat perjanjian kerja. Hal ini disebabkan oleh pihak pertama ingin memberikan ramburambu kepada pihak kedua agar tidak dilanggar, jelasnya untuk kepentingan perusahaan.

\section{Simpulan}

Dari hasil analisis dan pembahasan, disimpulkan bahwa:

a. Bentuk/jenis tindak tutur dalam surat 
perjanjian, yaitu: tindak tutur representatif (asertif), tindak tutur komisif, tindak tutur direktif, dan tindak tutur deklaratif. Selain keempat jenis tindak tutur tersebut, ditemukan juga jenis tindak tutur gabungan, yaitu tindak tutur asertif-komisif, tindak tutur direktifkomisif, tindak tutur asertif-deklaratif, dan tindak tutur komisif-deklaratif.

b. Fungsi tindak tutur yang terdapat dalam surat perjanjian kerja, yaitu untuk memutuskan (deklaratif), menyatakan (representatif), mengancam (komisif), dan memerintah (direktif).

Hasil ini menunjukkan bahwa bahasa yang terdapat dalam surat perjanjian kerja bersifat formal dan legal sehingga tidak dimungkinkan munculnya jenis tindak tutur yang bersifat ekspresif.

\section{Daftar Pustaka}

Alwi, Hasan, dkk. 2000. Tata Bahasa Baku Bahasa Indonesia, Edisi 3. Jakarta: Balai Pustaka.

Black, Elizabeth. 2011. Stilistika Pragmatis (Terjemahan dari judul asli Pragmatic Stylistics). Yogyakarta: Pustaka Pelajar.

Brown, Penelope and Stephen C. Levinson. 1987. Politeness: Some Universals in Language Usage. New York: Cambridge University Press.

Chaer, Abdul dan Agustina, Leonie. 2010. Sosiolinguistik: Perkenalan Awal. Jakarta: Rineka Cipta.

Cummings, Louise. 2007. Pragmatik(Terjemahan dari judul asli Pragmatics: A Multidiciplinary Perspective). Yogyakarta: Pustaka Pelajar.
Kesuma, Tri Mastoyo Jati. 2007. Pengantar (Metode) Penelitian Babasa. Yogyakarta: Penerbit Carasvatibooks.

Kridalaksana, Harimurti. 2004. Kamus Linguistik. (Edisi 4). Jakarta: PT Gramedia Pustaka Utama.

Mahsun. 2007. Metode Penelitian Bahasa: Tahapan Strategi, Metode, dan Tekniknya. (Edisi Revisi). Jakarta: PT Rajagrafindo Persada.

Mediawati, N. F., \& Phahlevy, R. R. 2015. The Importance of Employment Contract for Umsida Quality Employees Improvement Sidoarjo Jl . Majapahit Nomor 666 B, Sidoarjo, Jawa Timur, Indonesia, Kode Pos 61215, 2(39), 141-156.

Moleong, Lexy J. 2006. Metodologi Penelitian Kualitatif. Bandung: PT Remaja Rosdakarya.

Rustono. 1999. Pokok-Pokok Pragmatik. Semarang: CV IKIP Semarang Press.

Sapsford, Roger \& Victor Jupp. 2006. Data Collection and Analysis. (Second Edition). London, California, New Delhi: SAGE Publications Ltd.

Sudaryanto. 1993. Metode dan Aneka Teknik Analisis Bahasa: Pengantar Penelitian Wahana Kebudayaan Secara Linguistis. Yogyakarta: Duta Wacana University Press.

Verhaar, J.W.M. 2008. Asas-Asas Linguistik Umum. Yogyakarta: Gadjah Mada University Press.

Wijayanti, Sri Hapsari. 2009. "Bahasa Hukum Indonesia di dalam Surat Perjanjian" artikel di http://www.atmajaya.ac.id/ web/KontenUnit.aspx?gid=artikelhki\& ou=hki\&cid=artikel-hki-bahasa-hukumindonesia. Diakses pada tanggal 21 April 2016. 